\title{
Cortical and Cancellous Bone in Mandibular Symphysis. Implications in Osteosynthesis and Osteotomy
}

\author{
Hueso Cortical y Esponjoso en Sínfisis Mandibular. Implicancias en Osteotomía y Osteosíntesis
}

Humberto Velásquez¹; Sergio Olate ${ }^{2,3}$; Juan Pablo Alister ${ }^{2,4}$; Francisca Uribe ${ }^{2,4}$; Ziyad S. Haidar ${ }^{5,6}$ \& Rodrigo Fariña ${ }^{7,8}$

VELÁSQUEZ, V.; OLATE, S.; ALISTER, J. P.; URIBE, F.; HAIDAR, Z. S. \& FARIÑA, R. Cortical and cancellous bone in mandibular symphysis. implications in osteosynthesis and osteotomy. Int. J. Morphol., 35(3):1133-1139, 2017.

SUMMARY: The aim of this study was to quantify the presence of cortical and cancellous bone in the mandibular symphysis. A descriptive study was conducted using cone beam computed tomography where skeletal class I and class III subjects were included, defined according to characteristics detected on dental, clinical and dental occlusion x-rays. From the 3D reconstruction, sections were used in relation to the axial axis of the teeth of the anterior sector; the amount of buccal cortical, cortical, lingual, inferior cortical and cancellous bone as well as symphysis height were determined. The measurements were taken using routine methods and analyzed with ANOVA and Tukey's HSD test with $\mathrm{p}<0.05$ for statistical significance. 20 skeletal class I subjects aged 23 years $( \pm 4.5)$ and 20 class III subjects aged 22 years $( \pm 5.2)$ were included. Symphysis height was significantly greater in skeletal class III subjects, exceeding by $0.8 \mathrm{~mm}$ the height of class I subjects; the buccal cortical bone presented on average $2 \mathrm{~mm}$ less at different dental levels, whereas the lingual cortical and inferior basal bones were significantly larger than the buccal cortical bone. The cancellous and cortical bones did not present any significant differences between the two groups ( $\mathrm{p}=0.093$ ). The buccal and basilar cortical bone is smaller than lingual cortical bone.

KEY WORDS: Genioplasty; Mandibular symphysis; Chin.

\section{INTRODUCTION}

The mandibular symphysis is widely used in facial skeletal surgery; its anatomical study impacts directly on such functional and esthetic corrections as a genioplasty associated with orthognathic surgery (Olate \& de Moraes, 2014) as well as osteotomies to treat patients with a obstructive sleep apnea (Schendel et al., 2011).

Trauma of the anterior mandibular zone is also prevalent, where the osteosynthesis displays an important variety of techniques and materials (Madsen et al., 2008). Yet the precise anatomical study of the zone is needed to identify the best therapeutic options with low morbidity.

In this sense, facial deformities determine particular anatomical characteristics associated with the different types of deformities, which also demands adaptation in the application of some surgical techniques and in the observation of results (Pozzer et al., 2009); for that reason, previously, the authors have explored the symphysis anatomy, identifying characteristics of size and structure (Velásquez et al., 2015). The biomechanical conditions of the mandible make this zone key to the stability of the mandibular arch and to the response to different biomechanical demands of daily functioning (van Eijden, 2000).

The aim of this study was to quantify the cortical and cancellous bone in the mandibular symphysis and relate it to the teeth of the anterior area.

\section{MATERIAL AND METHOD}

A morphological study was conducted to measure the width of buccal cortical bone, inferior cortical bone, lingual cortical bone, cancellous bone and height of

\footnotetext{
${ }^{1}$ Master in Dental Sciences Program, Dental School, Universidad de La Frontera, Temuco, Chile.

${ }^{2}$ Division of Oral and Maxillofacial Surgery, Universidad de La Frontera, Temuco, Chile.

${ }^{3}$ Center for Morphological and Surgical Research (CEMYQ) Universidad de La Frontera, Temuco, Chile.

${ }^{4} \mathrm{PhD}$ Program in Medical Sciences, Universidad de La Frontera, Temuco, Chile.

${ }^{5}$ BioMAT’X, Dental School, Universidad de Los Andes, Santiago, Chile.

${ }^{6} \mathrm{PhD}$ Program in Biomedical Sciences, Universidad de Los Andes, Santiago, Chile.

${ }^{7}$ Department of Oral and Maxillofacial Surgery, Universidad de Chile, Santiago, Chile.

${ }^{8}$ Hospital El Salvador, Santiago, Chile.
} 
mandibular symphysis in adult subjects aged between 18 and 30 years with skeletal class I (Angle's class I) and class III (Angle's class III) with mandibular prognathism. Inclusion criteria were associated with the type of occlusion (Angle's type I or III), type of overjet (2 to $4 \mathrm{~mm}$ of sagittal relation for Angle's class I; -1 mm or less for Angle's class III) and definition of ANB angle ( 0 to $4^{\circ}$ for skeletal class I; $0^{\circ}$ or less for skeletal class III). Subjects who had another dental and/or skeletal class, subjects with facial malformations, subjects with facial asymmetries with chin deviation greater than $5 \mathrm{~mm}$ from the midline, and subjects with extractions or previous surgeries in the area of interest were excluded.

Subjects were recruited in the Division of Oral and Maxillofacial Surgery at the Universidad de La Frontera and agreed to participate in the study by signing aninformed consent. This study was approved by the Ethics Committee of the Universidad de La Frontera, Protocol $n^{\circ}$ 052/2015.

The study was conducted by analyzing images obtained from cone beam computed tomography (CBCT) taken in the maximum intercuspation position using the PlanMeca $^{\circledR}$ device (Korea); the images were analyzed in the EZ3D plus computer program (2009) by a single observer who took the measurements at two-week intervals; the correlation coefficient between the first and second measurement was 0.99 and presented a value of $\mathrm{p}=0.001$.

To take the measurements, the $3 \mathrm{D}$ image was positioned to establish the mandibular median line, setting the central bone point between the right and left lower central incisors, coinciding in its lower part with the mandibular median line. The 2D image was obtained from that position; then, for each tooth of interest, the image was moved from this central location until positioned on the tooth's axial axis that came in contact with the dental apex, so that each study area was kept at the same tilt and angulation.

The measurements were taken on the lower right canine (RC) and left canine (LC), lower right lateral incisor (RLI) and left incisor (LLI), lower right central incisor (RCI) and left incisor (LCI); in each of these teeth, 6 linear measurements were taken that interpreted the bone height in the area, the cortical bone thickness and the thickness of cancellous bone as follows (Fig. 1):

Line A: Straight line from the tooth apex to the lowest point of the basal area (in the cortical bone) of the tooth.

Line B: $5 \mathrm{~mm}$ below the apex of each tooth, a perpendicular line was made to line A from the lingual cortical bone to the buccal cortical bone. Line B corresponds to thewidth of cancellous bone measured between the internal point of the medial lingual cortical bone and the internal point of the buccal cortical bone.

Line C: $10 \mathrm{~mm}$ below the apex of each tooth, a second perpendicular line was made to line A from the lingual cortical bone to the buccal cortical bone. Line $\mathrm{C}$ corresponds to the width of cancellous bone measured between the internal point of the medial lingual cortical bone and the internal point of the buccal cortical bone.

Line D: In the same direction as line B, the distance was established between the most posterior and most anterior point of the buccal cortical bone.

Line E: In the same direction as line C, the distance was established between the most posterior and most anterior point of the buccal cortical bone.

Line F: In the same direction as line B and D, the distance was established between the most posterior and most anterior point of the lingual cortical bone.

Line G: In the same direction as line C, the distance was established between the most posterior and most anterior point of the lingual cortical bone.

Line F: In the same direction as line A, the distance was established between the highest and lowest point of the inferior cortical bone.

Each result was expressed in millimeters. The data were analyzed with a one-way ANOVA and Tukey's HSD test, considering a value of $\mathrm{p}<0.05$ to determine statistical significance.

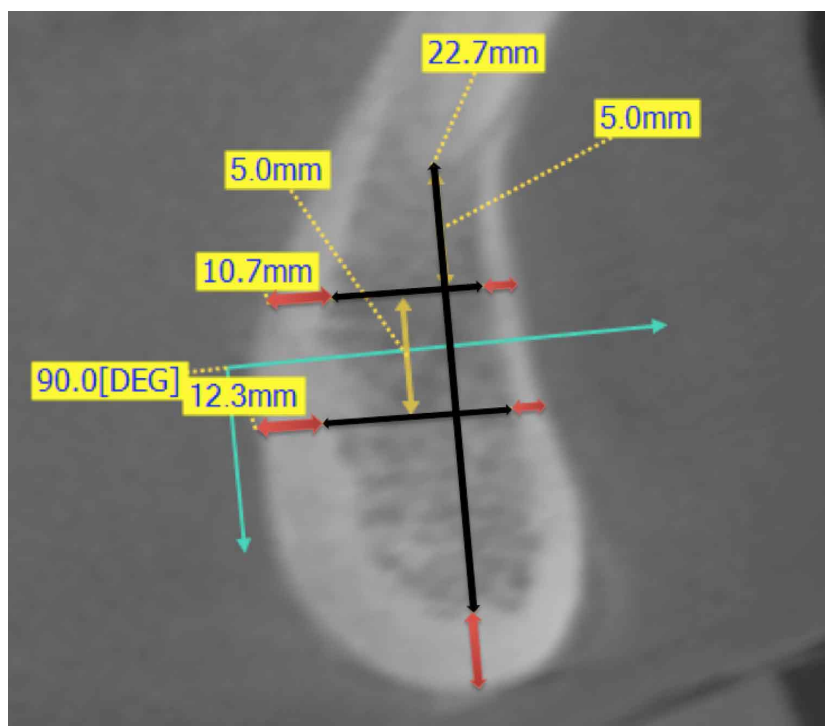

Fig. 1. Lines used to make the measurement in mandibular symphysis.

\section{RESULTS}

Group 1. 20 subjects were included in this group with an average age of 23 years $(+4.5), 12(66.6 \%)$ women and 6 $(33.3 \%)$ men.

In general terms (Table I), the vestibular cortical bone presented an average of $1.51 \mathrm{~mm}$ in the superior point and 


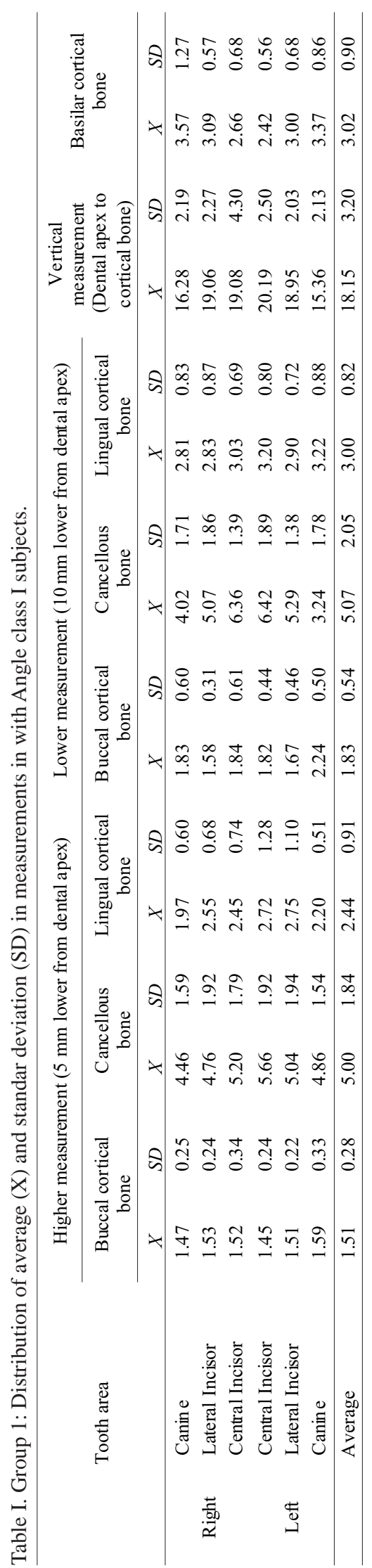

$1.83 \mathrm{~mm}$ in the inferior point and was consistently greater than the lingual cortical bone, with close to $1 \mathrm{~mm}$ more in the superior and inferior sectors $(2.44 \mathrm{~mm}$ in the superior zone and $3.00 \mathrm{~mm}$ in the inferior zone), and this was statistically significant $(\mathrm{p}=0.021)$. The basal cortical was larger than the lingual cortical bone, although it did not show any significant differences with the lingual zone $(\mathrm{p}=0.210)$; the cancellous bone observed was on average $5 \mathrm{~mm}$ from the superior point and 5.07 $\mathrm{mm}$ in the inferior point, being larger at the level of the central incisors and smaller at the canine level. In the inferior area, at the central incisor level, the amount of cancellous bone was statistically greater than the groups of lateral incisors and canines $(\mathrm{p}=0.048)$.

At the superior level (5 mm under the apex, Fig. 2) the amount of cortical bone (buccal and lingual) and cancellous bone presented an average of $8.95 \mathrm{~mm}$; at the inferior level (10 mm under the apex, Fig. 3), the same measurement (cortical

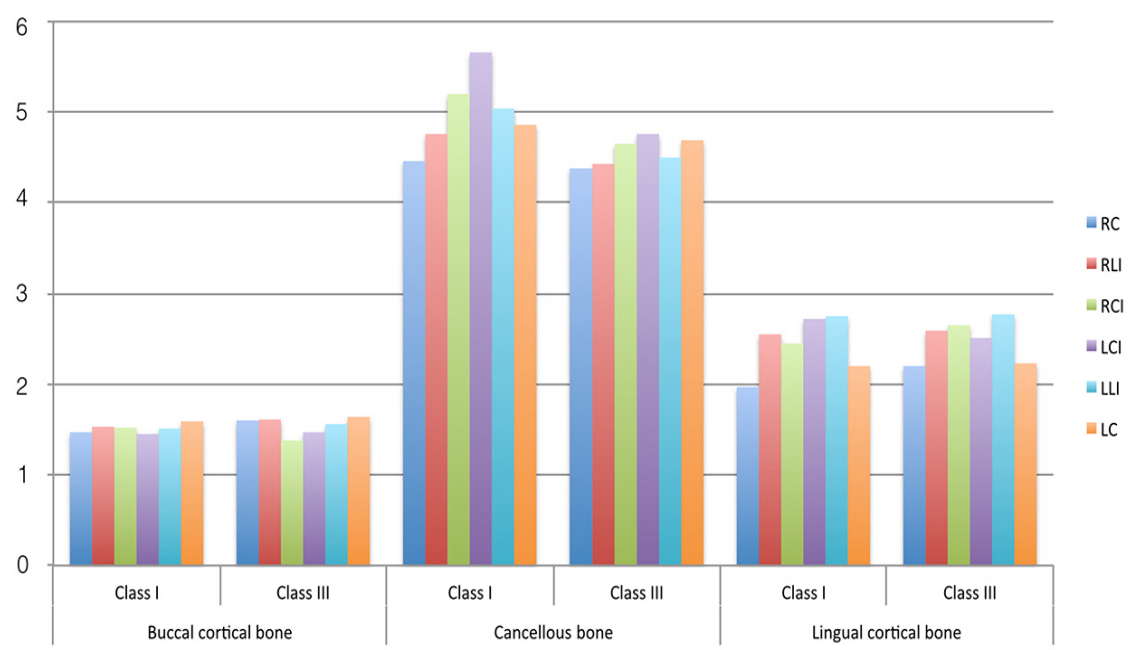

Fig. 2. Higher measurement obtained $5 \mathrm{~mm}$ lower from dental apex of right canine (RC), lateral incisor (RLI), central incisor (RCI) and left canine (LC), lateral incisor (LLI), central incisor (LCI).

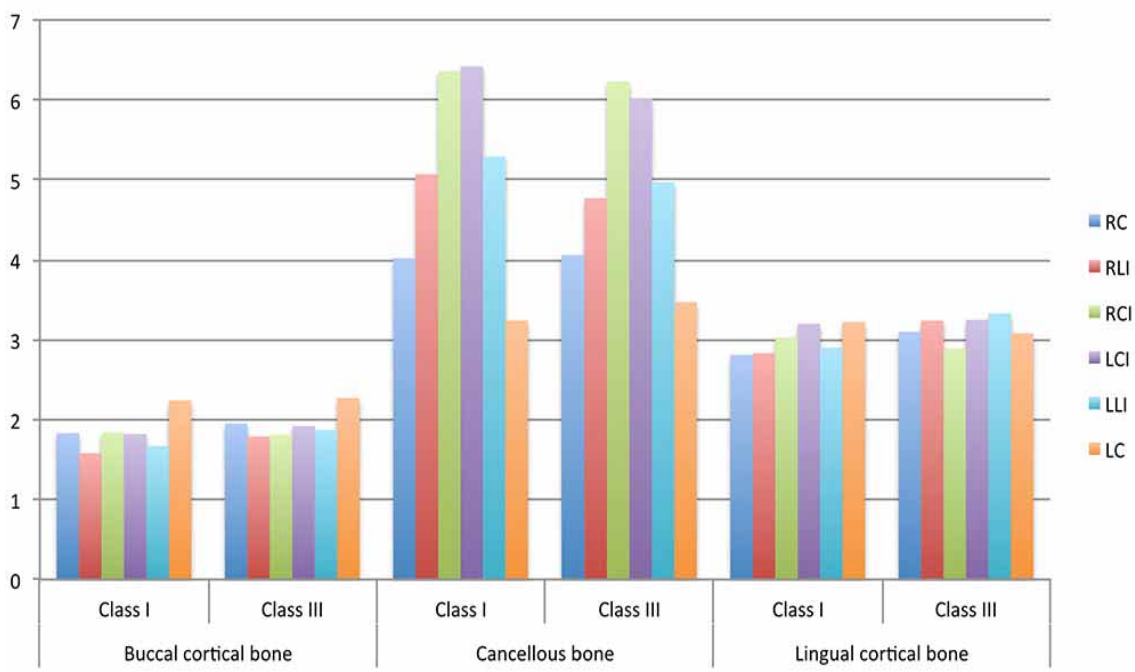

Fig. 3. Lower measurement obtained $10 \mathrm{~mm}$ lower from dental apex of right canine (RC), lateral incisor (RLI), central incisor (RCI) and left canine (LC), lateral incisor (LLI), central incisor (LCI). 


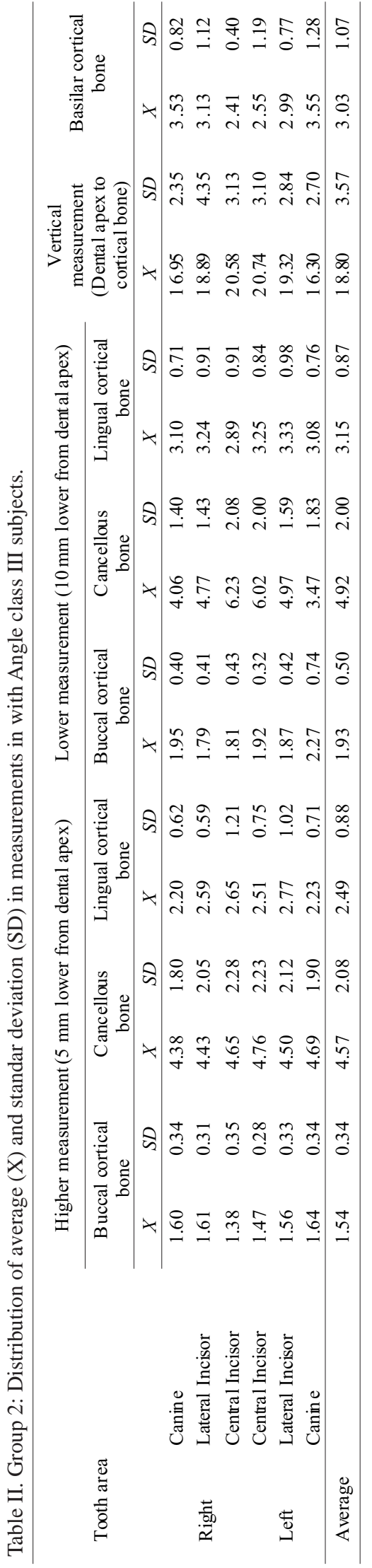

and cancellous) was $9.9 \mathrm{~mm}$. The differences were significant ( $\mathrm{p}=0.041)$, although it was mainly at the expense of differences in cortical bone. The symphysis height from the apical limit to the base was on average $18.15 \mathrm{~mm}$, being greater at central incisor level and less at canine level (Fig. 4); by contrast, the basal cortical bone was greater at canine level and less at central incisor level (Fig. 5).

Group 2. 20 subjects were included in this group with an average age of 22 years (+ 5.2), with $20(71.4 \%)$ women and $9(28.6 \%)$ men.

In general terms (Table II), the vestibular cortical bone presented an average of $1.54 \mathrm{~mm}$ in the superior point and $1.93 \mathrm{~mm}$ in the inferior point and was consistently larger than the lingual cortical bone, with close to $1.05 \mathrm{~mm}$ more in the superior and inferior sectors $(2.49 \mathrm{~mm}$ of lingual cortical bone in the superior area and $3.15 \mathrm{~mm}$ of lingual cortical bone in the inferior area), and this was statistically significant $(\mathrm{p}=0.030)$ just as in Group 1 . The basal cortical bone (average of $3.03 \mathrm{~mm}$ ) was larger than the lingual cortical bone, although it did not show any significant differences with the lingual zone; the cancellous bone observed

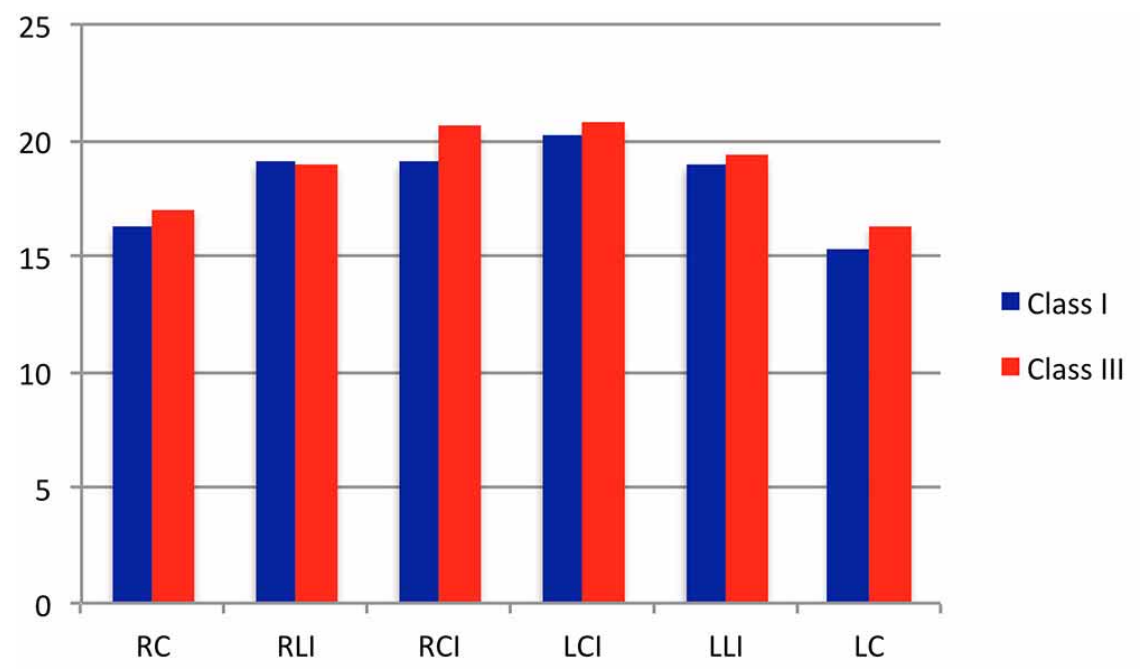

Fig. 4. Vertical measurement from dental apex to cortical bone in class I and class III subjects.

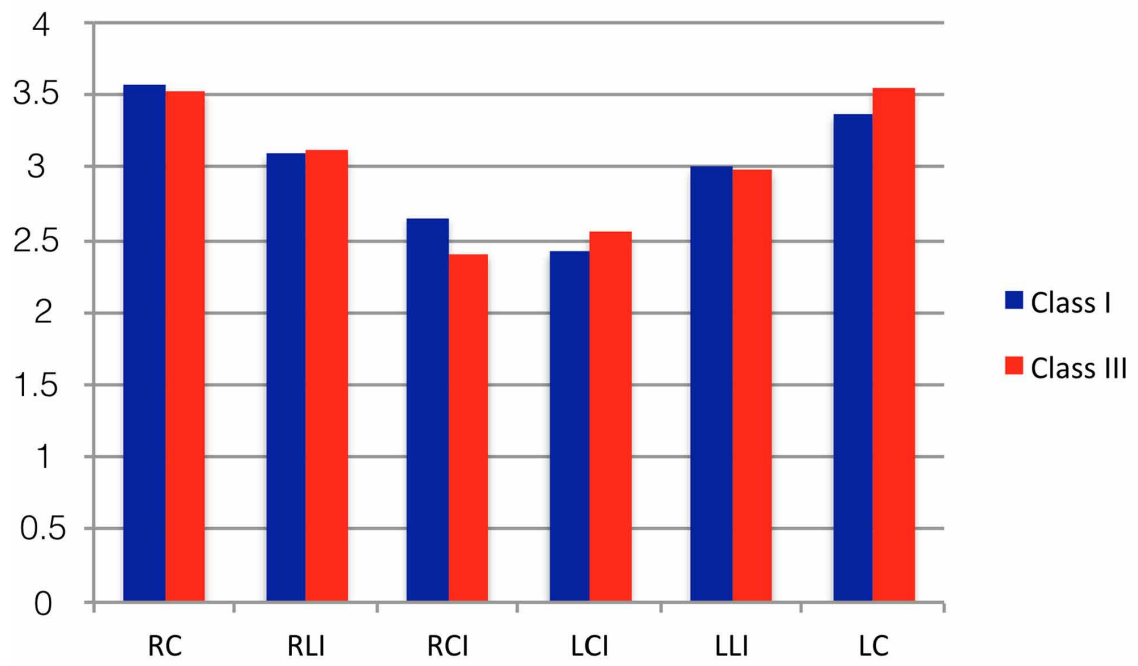

Fig. 5. Basilar cortical bone measurement in class I and class III subjects. 
was on average $4.57 \mathrm{~mm}$ of the superior zone and $4.92 \mathrm{~mm}$ in the inferior zone, being larger at the level of the central incisors and smaller at canine level. This area of cancellous bone was 0.15 and $0.05 \mathrm{~mm}$ smaller than in Group 1 in the different areas of measurement. In the inferior zone, at central incisor level, the amount of cancellous bone was statistically greater than the groups of lateral incisors and canines $(\mathrm{p}=0.003)$.

At the superior level, the total cortical (buccal and lingual) and cancellous bone presented an average of 8.6 $\mathrm{mm}(0.3 \mathrm{~mm}$ less than that observed in the same measurement in Group 1); at the inferior level (Fig. 2), the total cortical and cancellous bone was $10 \mathrm{~mm}$ (Fig. 3), which is almost no difference with the same area in Group 1. The symphysis height from the dental apical limit to the base was on average $18.80 \mathrm{~mm}$, being higher at central incisor level and lower at canine level.

\section{DISCUSSION}

The morphology and analysis of cortical and cancellous bone of the mandible is important due to the variety of surgical procedures performed in that area. The anterior zone of the mandible, however, has received poor attention. The position of cortical and cancellous bone is relevant in this zone since the mandibular symphysis is constantly subjected to surgeries to treat sleep apnea (Schendel et al.), esthetic genioplasty surgeries with different techniques (Assis et al., 2014) and trauma-related osteosyntheses (Madsen et al.).

Our results report significant differences between class I and class III subjects. Clinically, however, this difference may not be important, considering that some differences are less than a millimeter. It is possible that our sample influences the smaller differences observed in this investigation.

The cortical bone in both groups does not exceed 2 $\mathrm{mm}$ in the buccal sector and was almost $3 \mathrm{~mm}$ in the lingual sector. The lingual cortical sector and basal cortical sector, in both groups, were consistently thicker than the buccal cortical bone. It is possible that the lingual and cortical basal bone of the symphysis has a more important role in the mechanical resistance of the mandible than the anterior cortical bone (van Eijden), although these hypotheses must be examined in future studies.

Since the 1990s, the use of osteosynthesis associated with screws and plates in the mandible has been described as a safe technique, with low complication rates (Nakamura et al., 1994). It is considered that $5 \mathrm{~mm}$ under the apex of the tooth, there is a safety zone that reduces the risk of postoperative dental injuries; osteotomies and osteosynthesis must use this condition to reduce the risks. In this study, the total sagittal measurement of the mandibular symphysis was $8.95 \mathrm{~mm}$ (superior level) and $9.9 \mathrm{~mm}$ (inferior level) in dentoskeletal class I subjects and $8.60 \mathrm{~mm}$ (superior level) and $10.0 \mathrm{~mm}$ (inferior level) in class III subjects, which makes it possible to analyze the depth of penetration of the cutting and perforating elements used in osteotomies and osteosyntheses; greater deepening of the cutting elements in this area implies more options of soft tissue injury, with the resulting increased postoperative bleeding and edema due to soft tissue trauma.

Modifications proposals by some authors (Triaca et al., 2009; Fariña et al., 2012) promote high osteotomies, near the dental margin. Some recent publications have shown the presence of the incisor canal in this zone (Vu et al., 2015) as well as the possibilities of paresthesia and nerve disorders in osteotomies for obtaining of bone grafts. Taking our results into consideration, high osteotomies can create new risk variables for injury to the teeth adjacent to the osteotomy. Similarly, if the osteotomy is high, the osteosynthesis will be even higher, generating greater risks in the perforations made. The canine zone was never as high compared to central incisor area and this condition must be considered in modifications to osteotomies performed in the mandibular symphysis area.

In a research (Al-Jandan et al., 2013) studied 50 subjects using CBCT (18 to 33 years old), and at the apical level of the canine, an average buccal cortical bone of 1.78 mm was observed, determining that with $3 \mathrm{~mm}$ of perforation in this area there is a risk of dental injury. Our results, $5 \mathrm{~mm}$ under the area of the tooth apex, show cortical bones less than $2 \mathrm{~mm}$. Our results do not analyze the direct relation with tooth roots and it is not possible to define risks of direct damage to tooth roots in our study.

On other hand, 100 mandibles were analyzed by tomography of subjects between 33 and 87 years in their premolar area, identifying the installation of osteosynthesis plates in the area of the mental foramen (de Souza Fernandes et al., 2010). They reported that the distance from the buccal cortical bone to the tooth roots was approximately $3 \mathrm{~mm}$. Likewise, Fernandes et al. (2010) studied cadaver mandibles, concluding there is $3 \mathrm{~mm}$ of cortical bone in at least $77.5 \%$ of the cases and previous studies reported that the size of buccal cortical bone is approximately $3 \mathrm{~mm}$, indicating that this would be sufficient to insert screws with 3 turns to anchor securely in the cortical bone (Park et al., 1989). 
Although Champy et al., (1978) concluded that cortical support is enough to maintain the stability of the screws installed in the case of fractures, it has been described that in the case of genioplasty for chin advancement (Park et al.; Van Sickels et al., 1994) it is possible that the muscle package inserted in the lingual cortical bone may exert sufficient pressure to cause traction and recurrences of the procedure; in this sense, $2 \mathrm{~mm}$ in cortical bone in the buccal side could be not sufficient for plate support.

It has been shown that the length of the screw is not important in the mechanical resistance, but rather the number of screws per segment (Haug, 1993); others concluded that the width of the screw is relevant related to the size of the perforation made (Hughes \& Jordan, 1972). However, there is a difference in the mechanical response of $2 \mathrm{~mm}$ or 1.5 $\mathrm{mm}$ screws as well as in the length of the screw, where variations in the bone quality can affect the mechanical response of the system (Saka, 2000). Based on our results, 9 $\mathrm{mm}$ screws in the superior area and $10 \mathrm{~mm}$ in the inferior area can contribute to the bicortical function of the screw. In the case of monocortical screws, $2 \mathrm{~mm}$ of cortical bone present in the buccal sector seems insufficient to ensure segment stability. Additionally, in an experimental model (Kerawala et al., 2003) the possibility of compression with plates and monocortical screws was reported, highlighting the importance to the cortical bone in the area. Using the available bone, the ideal sector to install the screws is related to the central incisors, which present greater symphysis height compared to the canine zone.

We can conclude that the lingual cortical and basilar cortical bone is significantly greater than the buccal bone and the presence of cancellous bone is similar in class I and class III subjects. Comparative relations with subjects with Type II dentoskeletal deformity must be defined.

\section{ACKNOWLEDGMENTS}

The authors would like to thank the funding from the "UNETE project" of the Universidad de La Frontera (UNT 15-0008). Dr. Juan Pablo Alister and Dr. Francisca Uribe would like to thank the scholarship from CONICYT (CONICYT-PCHA/Doctorado Nacional/ 2015-21150598 and 2015-21150752), Chile.

VELÁSQUEZ, V.; OLATE, S.; ALISTER, J. P.; URIBE, F.; HAIDAR, Z. S. \& FARIÑA, R. Hueso cortical y esponjoso en sínfisis mandibular. implicancias en osteotomía y osteosíntesis. Int. J. Morphol., 35(3):1133-1139, 2017
RESUMEN: El objetivo fue determinar la presencia de hueso cortical y esponjoso en sínfisis mandibular. Se realizó un estudio descriptivo en tomografías computadorizadas cone beam donde se analizaron sujetos clase I y clase III esqueletal definidos según características dentales, clínicas y radiográficas de oclusión dental y características radiográficas. Desde la reconstrucción 3D se utilizaron cortes en relación al eje axial de los dientes del sector anterior; en ellos se determinó la cantidad de hueso cortical bucal, cortical, lingual, cortical inferior, hueso esponjoso y altura de sínfisis. Las mediciones fueron realizadas con métodos de rutina y fueron analizados con la prueba ANOVA y HDS Turkey considerando un valor de $\mathrm{p}<0.05$ para considerar significancia estadística. 20 sujetos clase I esqueletal con 23 años (+ 4.5) y 20 sujetos clase III esqueletal con edad de 23 años (+ 4.5) fueron incluidos. La altura de sínfisis fue significativamente mayor en sujetos de clase III esqueletal, superando por $0.8 \mathrm{~mm}$ la altura de sujetos clase I; el hueso cortical bucal presento en promedio menor de $2 \mathrm{~mm}$ en diferentes niveles dentarios, mientras que la cortical lingual y basal inferior fueron significativamente mayor que la cortical bucal. El hueso esponjoso y hueso cortical no presentó diferencias significativas entre ambos grupos $(\mathrm{p}=0.093)$. La cortical bucal y basilar son menores que el hueso cortical lingual.

PALABRAS ClAVE: Genioplastía; Sínfisis Mandibular; Mentón.

\section{REFERENCES}

Al-Jandan, B. A.; Al-Sulaiman, A. A.; Marei, H. F.; Syed, F. A. \& Almana, M. Thickness of buccal bone in the mandible and its clinical significance in mono-cortical screws placement. A CBCT analysis. Int. J. Oral Maxillofac. Surg., 42(1):77-81, 2013.

Assis, A.; Olate, S.; Asprino, L. \& de Moraes, M. Osteotomy and osteosynthesis in complex segmental genioplasty with double surgical guide. Int. J. Clin. Exp. Med., 7(5):1197-203, 2014.

Champy, M.; Loddé, J. P.; Schmitt, P.; Jaeger, J. H. \& Muster, D. Mandibular osteosynthesis by miniature screwed plates via a buccal approach. $J$. Maxillofac. Surg., 6(1):14-21, 1978.

de Souza Fernandes, A. C.; de Quadros Uzeda-Gonzalez, S.; Smith, R. L.; Alonso, L. G.; Gonzalez, F. M. \& Santos, M. V. Tomographic analysis of the interalveolar space and thickness of the vestibular cortical bone in the parasymphyseal region of adult human mandibles. Surg. Radiol. Anat., 32(10):951-6, 2010.

Fariña, R.; Valladares, S.; Aguilar, L.; Pastrian, J. \& Rojas, F. M-shaped genioplasty: a new surgical technique for sagittal and vertical chin augmentation: three case reports. J. Oral Maxillofac. Surg., 70(5):117782, 2012.

Fernandes, A. C.; Rossi, M. A.; Schaffner, I. S.; Machado, L. A. \& Sampaio, A. A. Lateral cortical bone thickness of human mandibles in region of mental foramen. J. Oral Maxillofac. Surg., 68(12):2980-5, 2010.

Haug, R. H. The effects of screw number and length on two methods of tension band plating. J. Oral Maxillofac. Surg., 51(2):159-62, 1993.

Hughes, A. N. \& Jordan, B. A. The mechanical properties of surgical bone screws and some aspects of insertion practice. Injury, 4(1):25-38, 1972.

Kerawala, C. J.; Allan, W. \& Williams, E. D. Can monocortical miniplates provide bony compression?. An experimental model. Br. J. Oral Maxillofac. Surg., 41(4):232-5, 2003.

Madsen, M. J.; McDaniel, C. A. \& Haug, R. H. A biomechanical evaluation of plating techniques used for reconstructing mandibular symphysis/ 
VELÁSQUEZ, V.; OLATE, S.; ALISTER, J. P.; URIBE, F.; HAIDAR, Z. S. \& FARIÑA, R. Cortical and cancellous bone in mandibular symphysis. implications in osteosynthesis and osteotomy. Int. J. Morphol., 35(3):1133-1139, 2017.

parasymphysis fractures. J. Oral Maxillofac. Surg., 66(10):2012-9, 2008.

Nakamura, S.; Takenoshita, Y. \& Oka, M. Complications of miniplate osteosynthesis for mandibular fractures. J. Oral Maxillofac. Surg., 52(3):233-8, 1994

Olate, S. \& de Moraes, M. Aesthetic facial surgery: Contribution from the anterior mandible osteotomy. Int. J. Med. Surg. Sci., 1(3):247-52, 2014.

Park, H. S.; Ellis, E. 3rd.; Fonseca, R. J.; Reynolds, S. T. \& Mayo, K. H. A retrospective study of advancement genioplasty. Oral Surg. Oral Med. Oral Pathol., 67(5):481-9, 1989.

Pozzer, L.; Olate, S.; Asprino, L. \& de Moraes, M. Are there differences in the mandibular morphometry in patients who are candidates for orthognathic surgery? Part 1: Influences of facial class. Int. J. Morphol., 27(3):751-6, 2009.

Saka, B. Mechanical and biomechanical measurements of five currently available osteosynthesis systems of self-tapping screws. Br. J. Oral Maxillofac. Surg., 38(1):70-5, 2000.

Schendel, S.; Powell, N. \& Jacobson, R. Maxillary, mandibular, and chin advancement: treatment planning based on airway anatomy in obstructive sleep apnea. J. Oral Maxillofac. Surg., 69(3):663-76, 2011.

Triaca, A.; Furrer, T. \& Minoretti, R. Chin shield osteotomy--a new genioplasty technique avoiding a deep mento-labial fold in order to increase the labial competence. Int. J. Oral Maxillofac. Surg., 38(11):1201-5, 2009.

van Eijden, T. M. Biomechanics of the mandible. Crit. Rev. Oral Biol. Med., 11(1):123-36, 2000

Van Sickels, J. E.; Smith, C. V.; Tiner, B. D. \& Jones, D. L. Hard and soft tissue predictability with advancement genioplasties. Oral Surg. Oral Med. Oral Pathol., 77(3):218-21, 1994.

Velásquez, H.; Olate, S.; del Sol, M.; Cantín, M. \& de Moraes, M. Osseous morphology in the mandibular symphysis. A pilot study. Int. J. Morphol., 33(1):355-60, 2015

Vu, D. D.; Brockoff, H. C. 2nd.; Yates, D. M.; Finn, R. \& Phillips, C Course of the mandibular incisive canal and its impact on harvesting symphysis bone grafts. J. Oral Maxillofac. Surg., 73(2):258.e1-e12, 2015.

\author{
Corresponding author: \\ Sergio Olate \\ Division of Oral and Maxillofacial Surgery \\ Claro Solar 115, Of. 414-A \\ Temuco \\ CHILE
}

\section{E-mail: sergio.olate@ufrontera.cl}

Received: 10-04-2017

Accepted: 25-06-2017 